\title{
Seagrass structural and elemental indicators reveal high nutrient availability within a tropical lagoon in Panama
}

\author{
Julie Gaubert-Boussarie ${ }^{1}$, Andrew Altieri ${ }^{2,3}{ }$, J. Emmett Duffy ${ }^{4}$, Justin E. Campbell ${ }^{\text {Corresp. } 1}$ \\ 1 Institute of Environment, Department of Biological Sciences, Florida International University, Miami, FL, United States \\ 2 Department of Environmental Engineering Sciences, University of Florida, Gainesville, FL, United States \\ 3 Smithsonian Tropical Research Institute, Smithsonian Institution, Panama City, Panama \\ 4 Tennenbaum Marine Observatories Network, Smithsonian Institution, Edgewater, MD, United States \\ Corresponding Author: Justin E. Campbell \\ Email address: jcamp013@fiu.edu
}

Seagrass meadows are valued coastal habitats that provide ecological and economic benefits around the world. Despite their importance, many meadows are in decline, driven by a variety of anthropogenic impacts. While these declines have been well documented in some regions, other locations (particularly within the tropics) lack long-term monitoring programs needed to resolve seagrass trends over time. Effective and spatially-expansive monitoring within under-represented regions is critical to provide an accurate perspective on seagrass status and trends. We present a comprehensive dataset on seagrass coverage and composition across 24 sites in Bahía Almirante, a lagoon along the Caribbean coast of Panama. Using a single survey, we focus on capturing spatial variation in seagrass physical and elemental characteristics and provide data on key seagrass bio-indicators, such as leaf morphology (length and width), elemental content (\% nitrogen and phosphorus) and stable isotopic signatures $\left(\delta^{13} \mathrm{C}\right.$ and $\left.\delta^{15} \mathrm{~N}\right)$. We further explore relationships between these variables and water depth (proxy for light availability) and proximity to shore (proxy for terrestrial inputs). The seagrass assemblage was mostly monospecific (dominated by Thalassia testudinum) and restricted to shallow water $(<3 \mathrm{~m})$. Above-ground biomass varied widely, averaging $71.7 \mathrm{~g}$ dry mass $\mathrm{m}^{-2}$, yet ranging from 24.8 to $139.6 \mathrm{~g}$ dry mass $\mathrm{m}^{-2}$. Leaf nitrogen content averaged $2.2 \%$, ranging from 1.76 to $2.57 \%$, while phosphorus content averaged $0.19 \%$ and ranged from 0.15 to $0.23 \%$. These values were high compared to other published reports for $T$. testudinum, indicating elevated nutrient availability within the lagoon. Seagrass stable isotopic characteristics varied slightly and were comparable with other published values. Leaf carbon signatures $\left(\delta^{13} \mathrm{C}\right)$ ranged from -11.74 to $-6.70 \%$ and were positively correlated to shoreline proximity, suggesting a 
ranged from -1.75 to $3.15 \%$ and showed no correlation with shoreline proximity, suggesting that $\mathrm{N}$ sources within the bay were not dominated by localized point-source discharge of treated sewage. Correlations between other seagrass bio-indicators and environmental metrics were mixed: seagrass cover declined with depth, while biomass was negatively correlated with $\% \mathrm{~N}$, indicating that light and nutrient availability may jointly regulate seagrass cover and biomass. Our work documents the response of seagrass in Bahía Almirante to light and nutrient availability and highlights the eutrophic status of this bay. Using the broad spatial coverage of our survey as a baseline, we suggest the future implementation of a continuous and spatially expansive seagrass monitoring program within this region to assess the health of these important systems subject to global and local stressors. 
1 Title: Seagrass structural and elemental indicators reveal high nutrient availability within 2 a tropical lagoon in Panama.

3

4 Authors: Julie Gaubert-Boussarie ${ }^{1}$, Andrew H. Altieri' ${ }^{2,3}$, J. Emmett Duffy ${ }^{4}$, Justin E. Campbell ${ }^{1 *}$

5 Affiliation: ${ }^{1}$ Department of Biological Sciences, Florida International University, Marine

6 Sciences Program, 3000 NE 151 Street, North Miami, Florida 33181, USA.

$7{ }^{2}$ Department of Environmental Engineering Sciences, University of Florida, Gainesville,

8 Florida, 32611, USA

$9{ }^{3}$ Smithsonian Tropical Research Institute, Apartado Postal 0843-03092, Panamá, Republic of

10 Panamá

$11{ }^{4}$ Tennenbaum Marine Observatories Network, Smithsonian Institution, Edgewater, MD 21037 ,

12 USA

13

$14 *$ Corresponding author: Justin E Campbell

15 Email address: jcampbel@fiu.edu

16

17

18

19

20

21

22

23

24

25

26

27

28

29

30

31

Peer] reviewing PDF | (2021:01:56950:1:0:NEW 15 Mar 2021) 
34 Abstract

Seagrass meadows are valued coastal habitats that provide ecological and economic

benefits around the world. Despite their importance, many meadows are in decline, driven by a

variety of anthropogenic impacts. While these declines have been well documented in some

regions, other locations (particularly within the tropics) lack long-term monitoring programs

needed to resolve seagrass trends over time. Effective and spatially-expansive monitoring within under-represented regions is critical to provide an accurate perspective on seagrass status and trends. We present a comprehensive dataset on seagrass coverage and composition across 24 sites in Bahía Almirante, a lagoon along the Caribbean coast of Panama. Using a single survey, we focus on capturing spatial variation in seagrass physical and elemental characteristics and provide data on key seagrass bio-indicators, such as leaf morphology (length and width), elemental content (\% nitrogen and phosphorus) and stable isotopic signatures $\left(\delta^{13} \mathrm{C}\right.$ and $\left.\delta^{15} \mathrm{~N}\right)$.

We further explore relationships between these variables and water depth (proxy for light availability) and proximity to shore (proxy for terrestrial inputs). The seagrass assemblage was mostly monospecific (dominated by Thalassia testudinum) and restricted to shallow water $(<3$ to $139.6 \mathrm{~g}$ dry mass $\mathrm{m}^{-2}$. Leaf nitrogen content averaged $2.2 \%$, ranging from 1.76 to $2.57 \%$, while phosphorus content averaged $0.19 \%$ and ranged from 0.15 to $0.23 \%$. These values were

52 high compared to other published reports for T. testudinum, indicating elevated nutrient 53 availability within the lagoon. Seagrass stable isotopic characteristics varied slightly and were 54 comparable with other published values. Leaf carbon signatures $\left(\delta^{13} \mathrm{C}\right)$ ranged from -11.74 to -

$556.70 \%$ and were positively correlated to shoreline proximity, suggesting a contribution of 
56 terrestrial carbon to seagrass biomass. Leaf nitrogen signatures $\left(\delta^{15} \mathrm{~N}\right)$ ranged from -1.75 to

$573.15 \%$ and showed no correlation with shoreline proximity, suggesting that $\mathrm{N}$ sources within the

58 bay were not dominated by localized point-source discharge of treated sewage. Correlations

59 between other seagrass bio-indicators and environmental metrics were mixed: seagrass cover

60 declined with depth, while biomass was negatively correlated with $\% \mathrm{~N}$, indicating that light and

61 nutrient availability may jointly regulate seagrass cover and biomass. Our work documents the

62 response of seagrass in Bahía Almirante to light and nutrient availability and highlights the

63 eutrophic status of this bay. Using the broad spatial coverage of our survey as a baseline, we

64 suggest the future implementation of a continuous and spatially expansive seagrass monitoring

65 program within this region to assess the health of these important systems subject to global and

66 local stressors.

67 Keywords: Thalassia testudinum, nitrogen, phosphorus, eutrophication, Bahía Almirante, Bocas

68 Del Toro, Caribbean, seagrass meadows, stable isotopes

\section{Introduction}

Seagrass meadows provide key ecological functions and ecosystem services in coastal

72 zones (Short et al. 2007; United Nations Environment Programme, 2020 ). These meadows

73 provide shelter and habitat for a variety of marine species, including endangered and iconic

74 species such as sea turtles, manatees and dugongs (Sievers et al. 2019), and their productivity

75 supports coastal food webs (Duarte \& Chiscano 1999). They form ecological connections with

76 other tropical ecosystems such as corals reefs and mangroves (Gillis et al. 2014) and support

77 high-value services such as nutrient cycling, sediment stabilization, and carbon sequestration

78 (Waycott et al. 2009; Fourqurean et al. 2012). Seagrasses are found in shallow coastal waters 
79 and estuaries around the world (Short et al. 2007) and although they cover around $0.1-0.2 \%$ of

80 the sea floor, they disproportionately provide a large number of services and are among the most

81 valuable ecosystems on the planet (Costanza et al. 1998).

82 Seagrass meadows are also one of the most threatened habitats (Orth et al. 2006), with

83 global losses estimated at $7 \%$ per year towards the end of the 20 th century and around $30 \%$ of

84 the known areal extent having disappeared since the first records in 1879 (Waycott et al. 2009).

85 This results from local anthropogenic activities such as habitat destruction, overfishing and

86 eutrophication. Other impacts are related to global factors including climate warming and sea-

87 level rise, which can lead to large-scale trends of seagrasses loss (Duarte 2002; Waycott et al.

88 2009). The decline of seagrasses is notable in the Caribbean Sea, where human population

89 expansion and tourism threaten many coastal habitats (Govers et al. 2014; van Tussenbroek et al.

90 2014).

91 In Panama, anthropogenic pressure is particularly noticeable in Bahía Almirante (e.g.

92 Cramer 2013; Seemann et al. 2018), a coastal semi-enclosed lagoon located on the northwest

93 Caribbean coast of Panama and delimited by the Bocas del Toro archipelago. This region has a

94 long history of banana agriculture and cacao production (Cramer et al. 2012; Fredston-Hermann

95 et al. 2013; Seemann et al. 2014), and is currently experiencing increases in cattle and teak tree

96 farming (Aronson et al. 2014). The resulting deforestation has led to an increase in erosion and

97 sediment runoff, elevating nutrient input into the bay and decreasing water quality (Seemann et

98 al. 2014).

99 Monitoring coastal habitats is crucial in the context of understanding both the scope and 100 scale of their global decline. Seagrasses can serve as useful indicators of the health of marine

101 habitats and a variety of environmental drivers (Short et al. 2006). In addition to seagrass cover 
102 and abundance, the elemental and isotopic composition of seagrass leaf tissue can serve as useful

103 indicators of their nutritional status and surrounding environmental conditions (Fourqurean et al.

104 2007; Campbell \& Fourqurean 2009). Elemental composition, particularly the content of

105 nitrogen $(\mathrm{N})$ and phosphorus $(\mathrm{P})$, along with calculated N:P ratios, can provide information on

106 the ambient and relative availability of nutrient resources (Fourqurean et al. 1992). Seagrass leaf

107 stable carbon isotope signatures $\left(\delta^{13} \mathrm{C}\right)$ can be used as a reliable indicator of (1) benthic light

108 availability or (2) inputs of carbon from terrestrial sources (Campbell \& Fourqurean 2009).

109 Further, leaf stable nitrogen isotopic signatures $\left(\delta^{15} \mathrm{~N}\right)$ can be used to infer both the availability

110 and source of dissolved inorganic nitrogen (DIN; Mcclelland et al. 1997).

111 Studies of seagrass cover in Bahía Almirante are relatively limited. Through the

112 Caribbean Coastal Marine Productivity Program (CARICOMP, 1998), data on seagrass temporal

113 variability and environmental parameters have been collected since 1998 near the Smithsonian

114 Tropical Research Institute's station in Bocas del Toro (Guzmán et al. 2005; López-Calderón et

115 al. 2013; van Tussenbroek et al. 2014). However, CARICOMP was limited to two sites and may

116 not reflect broader seagrass cover across the bay. Another study described T. testudinum nutrient

117 content among the three main water bodies of the Bocas archipelago (Carruthers et al. 2005),

118 however biomass and leaf morphometric data were not measured. Thus, bay-wide data on

119 seagrass cover and shoot morphometrics have yet to be published.

120

121 In this paper, we present a comprehensive dataset on seagrass percent cover and

122 distribution within Bahía Almirante in Bocas del Toro, Panama. We provide data on the

123 elemental and isotopic signature of surveyed seagrass meadows and compare these data with

124 values reported from other regions in the Caribbean to better understand the health and status of 
125 these meadows. These data may be used as baseline measurements for future comparative

126 surveys within this region. Seagrass cover and benthic community composition were surveyed

127 across 24 sites ranging from 0.5 to $8.8 \mathrm{~m}$ depth. Aboveground biomass and shoot morphology

128 (shoot area, leaf length and width) of the dominant species, Thalassia testudinum are reported,

129 along with leaf tissue elemental $(\% \mathrm{~N}, \% \mathrm{C}, \% \mathrm{P}, \mathrm{C}: \mathrm{N}, \mathrm{C}: \mathrm{P}$ and $\mathrm{N}: \mathrm{P}$ ratios $)$ and isotope content

$130\left(\delta^{13} \mathrm{C}\right.$ and $\left.\delta^{15} \mathrm{~N}\right)$. In order to understand some of the mechanisms behind the any trends in

131 seagrass meadow characteristics, we explored the potential relationships between site water

132 depth (proxy for light availability), site proximity to shore (proxy for potential terrestrial inputs)

133 and our measured variables (e.g. leaf tissue elemental and isotope contents, biomass).

134

\section{2. Materials \& Methods}

136 Study sites

137 The Bahía Almirante lagoon is $446 \mathrm{~km}^{2}$, extends to a maximum depth of $30 \mathrm{~m}$, and has

138 extensive seagrass meadows, corals reefs and mangroves (Guzmán et al. 2005). Bahía Almirante

139 receives moderate to high freshwater input (mean annual precipitation of approximately $3.3 \mathrm{~m}$ )

140 and as a result, extensive nutrient loading from the inflowing rivers (Phillips et al. 1997;

141 Carruthers et al. 2005). With a minimal tidal range $(<0.5 \mathrm{~m})$ and only three narrow connections

142 with the ocean, the water circulation inside the bay is limited (Carruthers et al. 2005; López-

143 Calderón et al. 2013). A total of 24 sites were surveyed across Bahia Almirante (see Fig.1 and

144 Table S1) in September 2015. Survey sites were selected by superimposing a grid (each cell 1

$145 \mathrm{~km}^{2}$ ) across the entire bay, and GPS coordinates of intersecting grid lines were used to locate 31

146 potential sites. GPS coordinates with no seagrass coverage were not included in our survey.

\section{Benthic community composition}


At each site, a $25 \mathrm{~m}$ transect line was deployed from the site coordinate along a consistent

149 depth, and photographs of replicate quadrats $\left(1 \mathrm{~m}^{2}\right)$ were taken every $5 \mathrm{~m}$ with an underwater

150 camera. Images were later imported into image software (Coral Point Count; Kohler \& Gill

151 2006), and percent cover of benthic organisms and bare sediment was determined from 50 points

152 randomly superimposed over each photograph. Benthic composition was then identified

153 underneath each point and assigned to one of the following broad taxonomic groups: seagrass, 154 coral, soft coral, sponge, fleshy algae and calcareous algae.

155

156

157

Seagrass sampling

158

Seagrass sampling for aboveground biomass (called areal biomass or biomass hereafter) consisted of collecting a single, $15 \mathrm{~cm}$-diameter cylinder core at each site. Seagrass cores were

160 haphazardly located within each meadow and within each core, all aboveground shoot biomass was collected, placed in a labeled bag, and returned to the lab on ice. Seagrasses (predominantly T. testudinum) were scraped free of fouling material and the length and width of leaves of all

163 shoots were recorded. Seagrass material was rinsed in deionized water (DI), dried to a constant

164 weight in a $70{ }^{\circ} \mathrm{C}$ oven and then dry mass was standardized to a $\mathrm{m}^{2}$ basis. An additional 5-6

165 shoots of the dominant seagrass (T. testudinum) were haphazardly harvested along each transect 166 and transported on ice for elemental and isotopic analysis. Afterwards, leaf material was 167 separated, rinsed in DI, scraped free of fouling and dried in a $70^{\circ} \mathrm{C}$ oven. Leaf material was 168 ground to a fine powder with a mortar and pestle.

169 
172 nutrient availability across extended time scales, leaf tissue $\mathrm{N}$ and $\mathrm{P}$ content can serve as a useful

173 gauge of mean ambient nutrient availability relative to spot measurements of water column

174 nutrient concentrations, which can be highly variable (Fourqurean et al. 1992). Leaf $\mathrm{N}$ content

175 was analyzed using a CHN analyzer and leaf P content was determined through dry oxidation

176 and acid hydrolysis extraction followed by a colorimetric analysis (Fourqurean et al. 1992).

177 Elemental ratios were calculated on a mole:mole basis. A limitation index (LI) was also

178 calculated as follows: $\mathrm{LI}=|30-\mathrm{N}: \mathrm{P}|$ (Campbell \& Fourqurean, 2009). This index is used to

179 quantify the degree of divergence from the ideal ca. 30:1 'Seagrass Redfield Ratio' (Atkinson \&

180 Smith, 1983; Duarte, 1990). Larger LI values indicate greater degrees of nutrient limitation.

181 Seagrass carbon isotopic composition can also serve as a useful bio-indicator of plant

182 health (overall photosynthetic activity). Prolonged declines in light availability, which reduce

183 photosynthetic carbon demand, often result in increased fractionation against the heavier carbon

184 isotope $\left({ }^{13} \mathrm{C}\right)$ and progressively lighter $\delta^{13} \mathrm{C}$ values (Fourqurean et al. 2019). However, it is

185 important to note that shifts in the concentration and source of dissolved inorganic carbon (DIC)

186 can also influence carbon isotope values (Durako \& Sackett 1993; Campbell \& Fourqurean

187 2011), thus relationships between $\delta^{13} \mathrm{C}$ and benthic light availability are strongest when the

188 source and concentration of DIC is relatively constant. For nitrogen, seagrasses fractionate the

189 source pool of DIN dependent upon the relative balance between pool size and plant demand

190 (Fourqurean et al. 2005). Thus, declines in $\delta^{15} \mathrm{~N}$ may reflect increases in the environmental

191 availability of DIN, or reductions in plant demand (potentially related to growth). However,

192 seagrass nitrogen isotope values may also reflect DIN source. Seagrass $\delta^{15} \mathrm{~N}$ signatures have

193 previously been used as an indicator of wastewater sources of $\mathrm{N}$, as microbial processing 
194 increases the $\delta^{15} \mathrm{~N}$ signature of the source DIN pool and can be reflected in seagrass tissue 195 (Fourqurean et al. 2015).

$196 \mathrm{C}$ and $\mathrm{N}$ isotope analyses were conducted using a standard elemental analyzer isotope

197 ratio mass spectrometer procedure. A separate elemental analyzer was used to combust all

198 organic material and subsequently reduce formed gasses into $\mathrm{N}_{2}$ and $\mathrm{CO}_{2}$, which were measured 199 on a Finnigan MAT Delta C Isotope Ratio Mass Spectrometer in continuous flow mode. The 200 samples' isotopic ratios (R) are reported in the standard delta notation $(\delta)$

$$
\delta(\% 0)=[(\text { Rsample } / \text { Rstandard })-1] \cdot 1000
$$

202 These results are presented with respect to the international standards of atmospheric nitrogen $203\left(\mathrm{~N}_{2}\right)$ and Vienna Pee Dee belemnite (V-PDB) for carbon.

204 We additionally conducted a literature review to compare our leaf $\mathrm{N}$ and $\mathrm{P}$ content to 205 values reported for T. testudinum in other regions across the Caribbean. Relevant literature was 206 searched with the database Google Scholar using the key words (Thalassia / Thalassia 207 testudinum and Caribbean), (Thalassia / Thalassia testudinum and nutrient or nitrogen or 208 phosphorus).

\section{Statistical analyses}

211 The normality of benthic community data (\% cover per group) and T. testudinum

212 elemental and isotopes composition was checked using the Shapiro-Wilk test. Standard linear 213 regressions were used to test the strength of the relationship between (1) depth and \% cover or 214 biomass, (2) biomass and $\% \mathrm{~N}, \% \mathrm{P}$, or $\% \mathrm{C},(3)$ shoot area and biomass or depth, and (4) $\delta^{13} \mathrm{C}$ or $215 \delta^{15} \mathrm{~N}$ and depth or distance to open ocean. Analyses were conducted using tidyverse (Wickham et 216 al. 2019) and ggplot2 (Wickham 2016) for graphical packages. Non-parametric correlations 
217 (Spearman's $\rho$ ) were assessed among elemental ratios, limitation index and biomass and water

218 depth. To investigate similarities in the benthic community composition between sites, the

219 benthic community data (\% cover per group, after arcsin transformation of these data) was used

220 in a cluster analysis (Bray-Curtis dissimilarity; vegdist and hclust functions). We used

221 Permutational Multivariate Analysis of Variance using distance matrices (PERMANOVA, 999

222 permutations, vegan package for R (Oksanen et al. 2020) to explore potential factors (e.g. depth,

223 distance from shore) that could explain the benthic community composition. Data visualization

224 and statistics were conducted using $\mathrm{R}$ software (version 3.6.2).

225

226 3. Results

227 Benthic community composition across Bahía Almirante

228 The benthic community in Bahia Almirante was dominated by turtlegrass, Thalassia

229 testudinum (mean \% cover $=51.95 \pm 5.85$ SE, Fig. 2), which was present at all seagrass sites.

230 Another seagrass species, Syringodium filiforme, was only observed at two sites, with a mean

231 percent cover of $0.24 \% \pm 0.22$. Bare space (sediment) was the second major component of

232 benthic cover (mean \% cover $=42.02 \pm 5.24$, Table S2). Other taxonomic groups were observed

233 in smaller abundances and frequency (Fig. 3 , Table S2): calcareous algae (mean \% cover= 3.44

$234 \pm 1.50)$, sponges (mean \% cover $=1.51 \pm 0.61)$, fleshy algae (mean $\%$ cover $=0.46 \pm 0.22)$, soft

235 corals (mean $\%$ cover $=0.19 \pm 0.19)$ and stony corals (mean $\%$ cover $=0.18 \pm 0.14)$. The $\%$ cover

236 of T. testudinum was negatively correlated with site depth $\left(\mathrm{r}^{2}=0.22, \mathrm{p}=0.027\right.$, Fig. $\left.4 \mathrm{a}\right)$.

237 A Bray-Curtis dissimilarity dendrogram on the benthic community showed three main

238 clusters (Fig. 5). The sites 13 and 17 formed one distinct cluster, as these two sites are in the

239 central-west part of Bahía Almirante where seagrass is sparse and the benthos is primarily 
240 composed of bare sediment ( 86.6 and $94.8 \%$ respectively). The second cluster grouped sites from

241 different locations in the bay and across different depths (primarily driven by Thalassia

242 dominance). The third cluster on the right of the dendrogram grouped sites from the south-east

243 part of the bay. Compared to the other sites, this third cluster had a more diverse bottom cover,

244 including sponges (percent cover from 0.82 to $9.64 \%$ ) and calcareous algae (percent cover from

2454.42 to $26.64 \%)$, along with cover of soft corals ( $4.08 \%$, one site) and fleshy algae ( $0.4 \%$ to

$2464.49 \%$ ) (Fig. 3 and S1). Except for the "central-west" and "south-east" clusters, no clear pattern

247 in the benthic community composition was found among sites according to depth, bay position,

248 distance from the ocean / closest town, the presence of a reserve area or the nutrient content in $T$.

249 testudinum leaf (PERMANOVA, $\mathrm{p}>0.05$; Table S3).

250

251

252

253

Thalassia testudinum biomass and morphometrics

254

Mean biomass of Thalassia testudinum was $71.7 \mathrm{~g}$ dry mass $\mathrm{m}^{-2} \pm 8.1( \pm \mathrm{SE})$, and tended

255 towards a bimodal distribution with values ranging from 24.8 to $139.6 \mathrm{~g}$ dry mass $\mathrm{m}^{-2}$ (Fig. 2,

256 Table 1). Unlike percent cover, T. testudinum biomass was not correlated with site depth ( $\mathrm{p}=$ 257 0.28, Fig. 4b).

The shoot morphometrics of $T$. testudinum were assessed from a sub-set of sites (16

259 total). The average shoot area was $6395 \pm 970 \mathrm{~mm}^{2}$, the average leaf length $190 \pm 18 \mathrm{~mm}$ and the

260 average leaf width $11 \pm 0.4 \mathrm{~mm}$ (Table 1). No correlations between shoot morphometrics and

261 areal biomass, depth or nutrient content $(\mathrm{p}>0.05)$ were found. 
263 Thalassia testudinum elemental and stable isotope composition.

264 The average \% content (dry mass) of $\mathrm{C}, \mathrm{N}$ and $\mathrm{P}$ were $38.77 \pm 0.46,2.20 \pm 0.04$ and 0.19

$265 \pm 0.00$ (mean $\pm \mathrm{SE}$ ) respectively, with a low variation among sites ( $\mathrm{CV}=0.06$ to 0.11 , Table 2 ).

266 The frequency distribution of the elemental ratios C:N (mean $20.7 \pm 0.39$ ), C:P (mean $537 \pm$

267 13.3) and N:P (mean 26.0 \pm 0.57 , Table 2) displayed a roughly normal distribution (Fig. 6), with 268 a low coefficient of variation among sites $(\mathrm{CV}=0.09-0.12)$. The limitation index (LI) exhibited 269 higher variation among sites $(\mathrm{CV}=0.52)$ and had a mean value of $4.30 \pm 0.46$ (Table 2). Stable 270 carbon isotope values displayed a slight bimodal distribution and varied from -11.74 to $-6.7 \%$ 271 (mean $-8.6 \pm 0.26 \%$ ) and stable nitrogen isotope values from -1.75 to $3.15 \%$ (mean $0.91 \pm$ $2720.28 \%$ ), and neither were correlated with site depth (Fig. 7c and d). The $\delta^{13} \mathrm{C}$ was negatively 273 correlated with the distance to the open ocean (Fig. 7e) but no similar correlation was found for $274 \delta^{15} \mathrm{~N}$. The $\% \mathrm{~N}$ of $T$. testudinum was negatively correlated with biomass $\left(\mathrm{r}^{2}=0.192, \mathrm{p}=0.032\right.$, Fig. 275 7a) but no correlation was found between biomass and $\% \mathrm{P}(\mathrm{p}=0.57$, Fig. $7 \mathrm{~b})$. Non-parametric 276 Spearman's correlations between depth, elemental and stable isotope ratios and LI were explored 277 (Table 3). Of these, depth was only positively correlated with C:P ratio. C:P and C:N were 278 positively correlated, as were $\mathrm{C}: \mathrm{P}$ and $\mathrm{N}: \mathrm{P}$. The $\delta^{15} \mathrm{~N}$ was positively correlated to $\mathrm{C}: \mathrm{N}$ and 279 negatively correlated to N:P. No correlation was found between the $\delta^{13} \mathrm{C}$ and the elemental 280 ratios.

281

282

283

284

285 286

\section{Discussion}

Growing human pressure has led to the decline of many coastal ecosystems in Bahía Almirante (Cramer 2013; Altieri et al. 2017), where agriculture, deforestation, tourism and urban construction have all triggered declines in the water quality across the bay (Guzmán et al. 2005). Our surveys provide the first comprehensive assessment of seagrass structural (biomass, shoot 
287 morphometrics) and chemical characteristics (elemental and isotopic content) and reveal most

288 meadows are (1) dominated by a single species (turtlegrass, Thalassia testudinum), (2) restricted

289 to shallow environments $(<3 \mathrm{~m}$ depth) and (3) display relatively high leaf $\mathrm{N}$ and $\mathrm{P}$ content. This

290 latter finding is of particular concern, as seagrasses at most sites could be classified as nutrient

291 replete $(\mathrm{N}: \mathrm{P}$ ratios near $30: 1$, and leaf $\mathrm{N}$ and $\mathrm{P}$ content higher than 1.8 and $0.2 \%$, respectively

292 Atkinson \& Smith, 1983; Duarte, 1990). No site displayed the low nutrient content which is

293 commonly observed in tropical seagrasses under oligotrophic settings. Comparisons of seagrass

294 nutrient content across the Caribbean (Fig. 8) supports the relatively eutrophic condition of Bahía

295 Almirante and highlights the vulnerable status of this ecosystem.

296 The benthic community at all sites was dominated by T. testudinum with limited

297 representation from other taxonomic groups (calcareous algae, sponges, fleshy algae, soft corals

298 and hard corals). It has been shown that the seagrass T. testudinum is a late successional species

299 which effectively competes for light and nutrients with some rhizophytic algae, a mechanism that

300 potentially explains the low presence of benthic macroalgae in our surveyed meadows (Davis \&

301 Fourqurean 2001). Furthermore, turtlegrass was also most abundant in shallower sites and

302 decreased with depth. Seagrass percent cover rapidly declined to nearly $25 \%$ as water depths

303 approached $4 \mathrm{~m}$ (Fig. 4a), and most seagrass in the lagoon was restricted to $<3 \mathrm{~m}$ deep and

304 relatively close to the mangrove shoreline. Thalassia testudinum is a large and long-lived species

305 with high below-ground biomass (up to $90 \%$ of its total biomass), thus it is restricted to high

306 light environments typically found in relatively shallow depths in order to maintain a positive

307 carbon balance (Fourqurean \& Zieman 1991; van Tussenbroek et al. 2014). Bahía Almirante is a

308 shallow lagoon, with most of the bay less than $10 \mathrm{~m}$ deep, and a maximum depth of $30 \mathrm{~m}$ in the

309 ship channel area (Aronson et al. 2014). While we found seagrasses as deep as $8.8 \mathrm{~m}$, coverage 
310 and biomass at depth were low. It appears that water-column productivity and rainfall-driven

311 turbidity generally prevent seagrasses from colonizing some of the deeper portions of the bay

312 which receive lower levels of light (Aronson et al. 2014).

313 Two of three site clusters based on benthic community similarity mapped to areas within

314 the bay. The cluster of two sites located in the central-west portion of the bay were mainly

315 composed of sand (Fig. 3, sites 13 and 17). One of these sites was relatively deep (5.8m) while

316 the other had heavy epiphytic growth on seagrass. Both factors likely reduced light availability

317 and limited seagrass abundance at this site. The cluster on the southeast part of the bay exhibited

318 higher benthic diversity as compared to most of the other sites, with sponges $(1.51 \pm 0.61 \%)$,

319 calcareous algae $(3.44 \pm 1.50 \%)$ and a small proportion of soft corals and fleshy algae at some

320 sites $(0.19 \pm 0.19 \%$ and $0.46 \pm 0.22 \%$, respectively). Due to the distance of the latter sites from

321 the main towns and their proximity to the open sea, it is possible that water quality and

322 recruitment rates may be higher there, resulting in higher benthic diversity. While two sampling

323 sites are in reserve areas (Site 4 is in Matumbal Bay Special Use Zone and Site 8 is in Isla

324 Bastimentos National Marine Park), they did not distinguish from the other sites in terms of

325 benthic community composition or biomass.

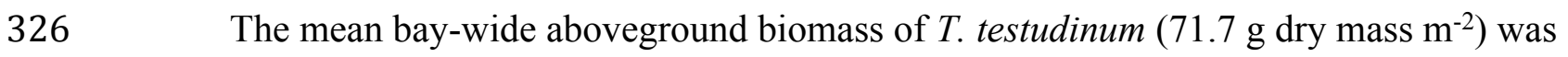

327 similar to other reported values at the Panama CARICOMP stations between 1999-2006 (mean:

$32877.4 \mathrm{~g}$ dry mass $\mathrm{m}^{-2}$, van Tussenbroek et al. 2014) and between 1999-2010 (mean: $66.6 \mathrm{~g}$ dry m-

329 2; López-Calderón et al. 2013). Mean T. testudinum biomass from our surveys was also similar

330 to values reported at other Caribbean CARICOMP stations (van Tussenbroek et al. 2014, see

331 table S4), however, these comparisons should be made with caution as there were generally only

332 2-4 sites / region in the CARICOMP program, compared to 24 sites in the current study. Thus, 
333 while regional means may be informative, our dataset documents large variation in seagrass

334 biomass $\left(24.8\right.$ - $139.6 \mathrm{~g}$ dry mass $\left.\mathrm{m}^{-2}\right)$ with nearly a third of our sites displaying extremely low

335 values $\left(20-40 \mathrm{~g}\right.$ dry mass $\left.\mathrm{m}^{-2}\right)$. Our 'within bay' variation was similar to the entire reported

336 range of seagrass biomass across all 52 CARICOMP sites $\left(16-325 \mathrm{~g}\right.$ dry mass $\left.\mathrm{m}^{-2}\right)$. As

337 CARICOMP is more targeted towards documenting long-term trends over time, our survey

338 focused on capturing spatial variation in seagrass physical and elemental characteristics at a

339 single time point, highlighting the distinctions between the two monitoring approaches.

340 Seagrass biomass displayed a bimodal distribution (Fig. 2), potentially indicating that

341 Bahía Almirante meadows may be broadly classified into one of two categories, either 'high' or

342 'low' biomass. Such may be the case if only shallow meadows are able to maintain high

343 biomass, while deteriorating conditions cause deeper meadows to converge towards a lower

344 biomass state because of declining light availability. Such a scenario would be supported by

345 increasingly pronounced bimodal distributions in future surveys. While we documented a

346 significant negative correlation between seagrass \% cover and depth, we did not find a strong

347 correlation between biomass and depth. This is because many of our shallow sites displayed high

348 visual percent cover, yet also had low estimates of biomass (Fig. 2), driven by the presence of

349 only a few shoots that were large enough to obscure a substantial portion of the benthic area

350 when viewed overhead. We also observed a negative correlation between seagrass biomass and

351 leaf tissue $\mathrm{N}$ content. $\mathrm{N}$ enrichment may have increased epiphyte growth and phytoplankton

352 blooms at certain sites, resulting in declining light availability to the leaf surface and

353 consequently decreasing seagrass aboveground biomass (Udy \& Dennison 1997; Lee \& Dunton

354 2000). Overall, prior work has similarly documented reduced seagrass biomass at depth and

355 under low light conditions (Duarte 1991), with differences in seagrass 'high' and 'low' biomass 
356 primarily driven by shifts in shoot density, and to a lesser extent, shoot size (Enríquez \& Pantoja-

357 Reyes 2005). Depth limits for T. testudinum depend upon overlying water clarity and range from $3581.2 \mathrm{~m}-30 \mathrm{~m}$ (Duarte 1991).

359 Seagrass elemental and isotopic content can give insights into their nutritional status and 360 surrounding environmental conditions (Fourqurean et al. 2007; Campbell \& Fourqurean 2009).

361 Mean elemental ratios for turtlegrass were higher in our study (2015) compared to prior surveys 362 (Carruthers et al. 2005): $\mathrm{C}: \mathrm{N}=20.60$ vs 15.1, $\mathrm{C}: \mathrm{P}=537.0$ vs 313.9 and $\mathrm{N}: \mathrm{P}=26.0$ vs 20.9 (see

363 S3 for a spatial comparison between survey sites). These slight increases may indicate a broader 364 trend of reduced nutrient availability across the bay over the past decade. However, we note that 365 as compared to other regions in the Caribbean, many of the meadows in Bahía Almirante are still 366 extremely nutrient replete (see Fig. 8 for a literature overview). The $\mathrm{N}$ and $\mathrm{P}$ content of $T$.

367 testudinum found in our study was near the high range of values reported from other areas (e.g.,

368 Bahamas, Belize, South Florida, Caribbean coast of Mexico). It has been hypothesized that 369 nutrient availability in Bahia Almirante is partly the result of high rainfall and runoff from a 370 highly impacted watershed, which has been subjected to both agriculture and deforestation 371 (Carruthers et al. 2005; Guzmán et al. 2005). In our study, no spatial pattern of seagrass nutrient 372 content was observed, thus we did not find any nutrient gradient from the mainland to the open 373 ocean, similar to other findings (Carruthers et al. 2005), suggesting that nutrient availability 374 across the bay is relatively homogeneous. The Bahía Almirante is relatively small, with a low 375 tidal range $(<0.5 \mathrm{~m})$ and only three narrow connections with the open ocean (Carruthers et al. 376 2005; López-Calderón et al. 2013), thus bay flushing is limited relative to the delivery of 377 nutrients from the inflowing creeks. 
379 (30:1; Atkinson \& Smith 1983; Duarte 1990), suggesting that seagrass growth was likely not 380 strongly limited by either $\mathrm{N}$ or $\mathrm{P}$. The recorded N:P ratio, close to the ideal Redfield value, may

381 be explained by the late successional status of this species, its slow growth rate, high ambient 382 nutrient availability and large below-ground biomass which can facilitate the access to sediment 383 nutrient pools (Williams 1987; Campbell \& Fourqurean 2009). Given the nutrient-replete status 384 of all sites, it is likely that the deeper meadows, which are characterized by low seagrass cover, 385 are light-limited. (coefficient $=0.46$ ). The $\delta^{15} \mathrm{~N}$ of $T$. testudinum was not correlated to site depth, however we note that this was being driven by the presence of one outlier site (Fig. 3f). When re-analyzed without this site, we found a significant negative relationship between depth and leaf $\delta^{15} \mathrm{~N}$, which is expected as deeper meadows with lower productivity can discriminate more strongly against the heavier nitrogen isotope. This is supported by the significant positive correlation between leaf $\delta^{15} \mathrm{~N}$ and $\mathrm{C}: \mathrm{N}$ ratios. Overall, most leaf $\delta^{15} \mathrm{~N}$ values were relatively light $(<2 \%$ ), likely driven by 393 a combination of both high $\mathrm{N}$ availability and potentially a light DIN pool from agricultural 394 sources (such as the banana farms in the Bocas watershed), as artificial fertilizer displays a $\delta^{15} \mathrm{~N}$ 395 near $0 \%$ (Chalk et al. 2014). Not a single site could be characterized as nutrient-limited within our survey. Median LI (4.12) was similar to values previously reported for this species in the Florida Keys (6.2), but our maximum value was five times lower than the maximum value reported in the Florida Keys 399 (9.08 vs 46.5), suggesting high nutrient availability throughout the entire bay. Seagrasses are 400 generally dominant in oligotrophic conditions and as nutrient availability increases, other 
401 primary producers with higher nutrient demands (macroalgae, epiphytic microalgae,

402 phytoplankton) can benefit and potentially out-compete seagrasses for light (Fourqurean \&

403 Rutten, 2003). As T. testudinum in Bahía Almirante appeared nutrient replete at all studied sites,

404 a further enrichment of the bay may be detrimental via competition with faster growing species

405 that could tip the system towards an algal-dominated state.

406 The mean $\delta^{13} \mathrm{C}$ of $T$. testudinum leaves is within the range reported for this seagrass (Lin

407 et al. 1991), and contrary to what was expected (see methods), no correlation was found between

408 depth and $\delta^{13} \mathrm{C}$ or $\delta^{15} \mathrm{~N}$. We only document a correlation between $\delta^{13} \mathrm{C}$ and the distance to the

409 open ocean, with an increase of $\delta^{13} \mathrm{C}$ in the sites closer to the open ocean. Bahía Almirante is a

410 high rainfall area, surrounded by extensive mangrove forests (Guzmán et al. 2005), and this

411 proximity to mangroves influences the inorganic carbon sources into the bay, potentially

412 influencing the $\delta^{13} \mathrm{C}$ of seagrass leaf tissue (Lin et al. 1991). Respiratory $\mathrm{CO}_{2}$ from the

413 decomposition and mineralization of mangroves detritus has low $\delta^{13} \mathrm{C}$ values. Therefore, the

414 relationship between depth and $\delta^{13} \mathrm{C}$ may have been obscured by the influence of a relatively

415 light carbon source. Moreover, in the open ocean, $\delta^{13} \mathrm{C}$ of the DIC pool tends to be close to $0 \%$

416 (Lloyd 1964; Hoefs, 1987; Lin et al. 1991), thus sites in closer proximity to the open ocean may

417 have been exposed to a heavier DIC pool and exhibited higher (less negative) leaf $\delta^{13} \mathrm{C}$ as

418 compared to sites closer to shore.

\section{Conclusions}

421 The elemental composition (high $\mathrm{N}$ and $\mathrm{P}$ content) and depth-restricted distribution of 422 seagrasses in Bahia Almirante suggest that these waters are relatively eutrophic. Comparisons

423 with other published values across the Caribbean reveal that seagrasses in the Bocas Del Toro 
424 region rank as second highest regarding $\mathrm{N}$ and $\mathrm{P}$ content. Combined with the finding that most

425 seagrass cover is limited to $<3 \mathrm{~m}$ depth, it is possible that many meadows may be approaching, or

426 have already surpassed, a 'tipping point' towards seagrass loss, in which the first indicators

427 would be deeper meadows losing all coverage and/or shallow meadows becoming sparsely

428 populated with high epiphytic growth. Using our surveys as a baseline dataset, we encourage the

429 establishment of a comprehensive and spatially-expansive monitoring program to assess the

430 future health and trajectory of these important systems. While the Bocas Del Toro watershed has

431 historically been highly impacted, we remain optimistic that these meadows have the potential to

432 recover, dependent upon future efforts to mitigate precipitation-driven nutrient input from the

433 surrounding watershed. Given that many meadows globally have experienced declines, multi-

434 faceted monitoring programs are needed to understand why some have displayed surprising

435 resilience (O’Leary et al. 2017) serving as ecological "bright spots" in the face of environmental

436 disturbance.

437

\section{Acknowledgements}

439 We thank Dean Janiak Scott Jones, Sean Mattson, Janina Seeman and Ross Whippo for help in

440 the lab and field. We also thank the Seagrass Ecosystems Research Lab (SERL) and Stable

441 Isotope Lab (SIL) at Florida International University (FIU) for assisting with sample processing.

442 A special thanks goes to Tim Carruthers for providing additional information from prior surveys

443 in Bahia Almirante. Funding was provided by the Smithsonian’s Tennenbaum Marine

444 Observatories Network and MarineGEO program. This is contribution xx from the Center for

445 Coastal Oceans in the Institute of Environment at FIU, contribution xx from the Smithsonian 
446 Tropical Research Institute, and contribution xx from the Smithsonian's MarineGeo and

447 Tennenbaum Marine Observatories Network.

448

449

450

Figures and tables captions

451

452 Table 1. Percentage cover in transects, average shoot morphometrics (shoot area, leaf length and

453 leaf width) and biomass (aboveground) of Thalassia testudinum across sites in Bahía Almirante

454 ( $\mathrm{SE}=$ standard error, $\mathrm{CV}=$ coefficient of variation).

455

456 Table 2. Elemental content and stable isotope ratios of Thalassia testudinum leaves collected 457 across the 24 sites in Bahía Almirante. $(\% \mathrm{~N}, \% \mathrm{C}$ and $\% \mathrm{P}$ are $\%$ of dry weight). LI= limitation 458 index, $\mathrm{n}=24$.

459

460 Table 3. Correlations (non-parametric Spearman's $\rho$ ) among elemental and stable isotope ratios,

461 LI and biomass of Thalassia testudinum and water depth. Correlation coefficients are indicated

462 above the diagonal and the $\mathrm{p}$-values (pairwise comparisons) are below. Significant $(\mathrm{p}<0.05)$

463 correlations are indicated in bold. LI: Limitation Index.

464 Figure 1. Map of Bahía Almirante in the Bocas del Toro archipelago, Panama showing the 24

465 sampling sites used in this study (see table S1 for details).

466 Figure 2. Frequency distribution of the \% cover, biomass, leaf width of Thalassia testudinum, 467 across sites in Bahía Almirante ( $\mathrm{n}=22$ for $\%$ Thalassia, $\mathrm{n}=24$ for the biomass and $\mathrm{n}=16$ for the 468 leaf width). 
470 Figure 3. Benthic community composition across the sites throughout Bahía Almirante.

471

472 Figure 4. Relationship between (a) the \% cover of Thalassia testudinum (y scale is $\log 10$

473 transformed) and depth, and (b) its biomass and depth. Linear regression and 95\% confidence

474 interval (gray area) of the regression are indicated.

475

476 Figure 5. Bray-Curtis dissimilarity cluster analysis of benthic community composition across 477 sites in Bahía Almirante.

478

479 Figure 6. Frequency distributions of elemental $(\mathrm{C}: \mathrm{N}, \mathrm{C}: \mathrm{P}$ and $\mathrm{N}: \mathrm{P})$ and stable isotopes $\left(\delta^{13} \mathrm{C}\right.$ and $\left.480 \delta^{15} \mathrm{~N}\right)$ ratios of Thalassia testudinum across the sites in Bahía Almirante $(\mathrm{n}=24)$. For each 481 parameter, the median and the mean values are indicated by a black and a blue line, respectively. 482 Red lines indicate the mean values of these parameters previously found in Bahia Almirante 483 (Carruthers et al. 2005). See Fig. S3 for a comparison between the survey sites of the current 484 study and Carruthers et al. 2005.

485

486 Figure 7. Relationship between (a) Thalassia testudinum biomass and \%N (dry mass) or (b) \%P 487 (dry mass), (c) depth and leaf $\delta^{13} \mathrm{C}$ or (d) leaf $\delta^{15} \mathrm{~N}$ and (e) the distance to the open sea 488 (Caribbean) and leaf $\delta^{13} \mathrm{C}$. Linear regression and 95\% confidence interval (gray area) of the 489 regression are indicated.

490 
491 Figure 8. Thalassia testudinum leaf nitrogen (\% N, dry mass) and phosphorus (\% P, dry mass)

492 content from different regions in the Caribbean, taken from the published literature. Regions are

493 ordered (top to bottom) by the mean value (highest to lowest) for each nutrient. Numbers in

494 square brackets correspond to the overall nutrient mean and total number of sites for each region.

495 Each point represents a studied area for which the mean value ( \pm SE when available, represented

496 by horizontal lines) was derived from the indicated reference in parenthesis (one color per

497 reference, see Table S5 for the complete list of references).

498 References

499

500 Altieri, A.H., Harrison, S.B., Seemann, J., Collin, R., Diaz, R.J. \& Knowlton, N. (2017). Tropical

501 dead zones and mass mortalities on coral reefs. PNAS, 114, 3660-3665.

502 Aronson, R.B., Hilbun, N.L., Bianchi, T.S., Filley, T.R. \& Mckee, B.A. (2014). Land use, water

503 quality, and the history of coral assemblages at Bocas del Toro, Panamá. Mar. Ecol. Prog.

$504 \quad$ Ser., 504, 159-170.

505 Atkinson, M.J. \& Smith, S. V. (1983). C : N : P ratios of benthic marine plants. Limnol.

$506 \quad$ Oceanogr., 28, 568-574.

507 Campbell, J.E. \& Fourqurean, J.W. (2009). Interspecific variation in the elemental and stable

508 isotope content of seagrasses in South Florida. Mar. Ecol. Prog. Ser., 387, 109-123.

509 Campbell, J.E. \& Fourqurean, J.W. (2011). Novel methodology for in situ carbon dioxide

510 enrichment of benthic ecosystems. Limnol. Oceanogr. Methods, 9, 97-109.

511 CARICOMP (1998). CARICOMP-Caribbean coral reef, seagrass and mangrove sites. Coastal

512 Region and Small Island Papers 3, UNESCO, Paris, XIV, France.

513 Carruthers, T.J.B.C., Barnes, P.A.G.B., Jacome, G.E.J. \& Fourqurean, J.W.F. (2005). Lagoon

514 scale processes in a coastally influenced Caribbean system : Implications for the seagrass 
Thalassia testudinum. Caribb. J. Sci., 41, 441-455.

516 Chalk, P.M., Inácio, C.T. \& Magalhães, A.M.T. (2014). From fertilizer to food: Tracing nitrogen

517 dynamics in conventional and organic farming systems using $15 \mathrm{~N}$ natural abundance. In:

518 International Symposium on Managing Soils for Food Security and Climate Change

519 Adaptation and Mitigation (eds. Heng, L.K., Sakadevan, K., Dercon, G. \& Nguyen, M.L.).

520 Food and Agriculture Organization of the United Nations, Rome, pp. 339-348.

521 Costanza, R., Groot, R. De, Farber, S., Grasso, M., Hannon, B., Limburg, K., Neill, R.V.O.,

522 Paruelo, J., Raskin, G., Sutton, P. (1998). The value of the world's ecosystem services and

523 natural capital. Ecol. Econ., 25, 3-15.

524 Cramer, K.L. (2013). History of human occupation and environmental change in western and 525 central Caribbean Panama. Bull. Mar. Sci., 89, 955-982.

526 Cramer, K.L., Jackson, J.B.C., Angioletti, C. V., Leonard-Pingel, J.S. \& Guilderson, T.P. (2012).

527 Anthropogenic mortality on coral reefs in Caribbean Panama predates coral disease and $528 \quad$ bleaching. Ecol. Lett., 15, 561-567.

529 Davis, B.C. \& Fourqurean, J.W. (2001). Competition between the tropical alga , Halimeda 530 incrassata, and the seagrass, Thalassia testudinum. Aquat. Bot., 71, 217-232.

531 Duarte, C.M. (1990). Seagrass nutrient content. Mar. Ecol. Prog. Ser., 67, 201-207.

532 Duarte, C.M. (1991). Seagrass depth limits. Aquat. Bot., 40, 363-377.

533 Duarte, C.M. (2002). The future of seagrass meadows. Environ. Conserv., 29, 192-206.

534 Duarte, C.M. \& Chiscano, C.L. (1999). Seagrass biomass and production : a reassessment. 535 Aquat. Bot., 65, 159-174.

536 Durako, M.J. \& Sackett, W.M. (1993). Effects of CO2 (aq) on the carbon isotopic composition 537 of the seagrass Thalassia testudinum Banks ex Kiinig ( Hydrocharitaceae). J. Exp. Mar. Bio. 


$$
\text { Ecol., 169, 167-180. }
$$

539 Enríquez, S. \& Pantoja-Reyes, N.I. (2005). Form-function analysis of the effect of canopy

540 morphology on leaf self-shading in the seagrass Thalassia testudinum. Oecologia, 145,

$541 \quad 235-243$.

542 Fourqurean, J.W., Duarte, C.M., Kennedy, H., Marbà, N., Holmer, M., Mateo, M.A., Apostolaki,

543 E.T., Kendrick, G.A., Krause-Jensen, D. (2012). Seagrass ecosystems as a globally

$544 \quad$ significant carbon stock. Nat. Geosci., 5, 1-5.

545 Fourqurean, J.W., Escorcia, S.P., Anderson, W.T. \& Zieman, J.C. (2005). Spatial and seasonal

546 variability in elemental content, d13 C, and d15 N of Thalassia testudinum from South

$547 \quad$ Florida and its implications for ecosystem studies. Estuaries, 28, 447-461.

548 Fourqurean, J.W., Manuel, S.A., Coates, K.A., Kenworthy, W.J. \& Boyer, J.N. (2015). Water

549 quality, isoscapes and stoichioscapes of seagrasses indicate general P limitation and unique

$550 \quad \mathrm{~N}$ cycling in shallow water benthos of Bermuda. Biogeosciences, 12, 6235-6249.

551 Fourqurean, J.W., Manuel, S.A., Coates, K.A., Massey, S.C. \& Kenworthy, W.J. (2019).

552 Decadal monitoring in Bermuda shows a widespread loss of seagrasses attributable to

553 overgrazing by the green sea turtle Chelonia mydas. Estuaries and Coasts, 42, 1524-1540.

554 Fourqurean, J.W., Marbà, N., Duarte, C.M., Diaz-Almela, E. \& Ruiz-Halpern, S. (2007). Spatial

555 and temporal variation in the elemental and stable isotopic content of the seagrasses

556 Posidonia oceanica and Cymodocea nodosa from the Illes Balears, Spain. Mar. Biol., 151, 557 219-232.

558 Fourqurean, J.W., Rutten, L.M. (2003). Competing goals of spatial and temporal resolution:

559 monitoring seagrass communities on a regional scale. In: Busch, D.E., Trexler, J.C. (Eds.),

$560 \quad$ Monitoring Ecosystems. Island Press, Chapter 10. 
561 Fourqurean, J.W. \& Zieman, J.C. (1991). Photosynthesis, respiration and whole carbon budget 562 of the seagrass Thalassia testudinum. Mar. Ecol. Prog. Ser., 69, 161-170.

563 Fourqurean, J.W., Zieman, J.C. \& Powell, G.V.N. (1992). Relationships between porewater 564 nutrients and seagrasses in a subtropical carbonate environment. Mar. Biol., 114, 57-65.

565 Fredston-Hermann, A.L., Dea, A.O., Rodriguez, F., Thompson, W.G. \& Todd, J.A. (2013).

566 Marked ecological shifts in seagrass and reef molluscan communities since the mid-

567 Holocene in the southwestern Caribbean. Bull. Mar. Sci., 89, 983-1002.

568 Gillis, L.G., Bouma, T.J., Jones, C.G., Katwijk, M.M. Van, Nagelkerken, I., Jeuken, C.J.L.,

569 Herman, P M J, Ziegler, A.D. (2014). Potential for landscape-scale positive interactions 570 among tropical marine ecosystems. Mar. Ecol. Prog. Ser., 503, 289-303.

571 Govers, L.L., Lamers, L.P.M., Bouma, T.J., Brouwer, J.H.F. De \& Katwijk, M.M. Van. (2014).

572 Eutrophication threatens Caribbean seagrasses - An example from Curaçao and Bonaire. $573 \quad$ Mar. Pollut. Bull., 89, 481-486.

574 Guzmán, H.É.M., Barnes, P.E.A.G., Lovelock, C.A.E. \& Feller, I.L.K.A.C. (2005). A Site

575 Description of the CARICOMP Mangrove, seagrass and coral reef sites in Bocas del Toro, 576 Panama. Caribb. J. Sci., 41, 430-440.

577 Hoefs, S., 1987. Stable Isotope Geochemistry. Springer-Verlag, New York, NY, 3rd ed. 241 pp. 578 Kohler, K.E. \& Gill, S.M. (2006). Coral Point Count with Excel extensions ( CPCe ): A Visual 579 Basic program for the determination of coral and substrate coverage using random point 580 count methodology. Comput. Geosci., 32, 1259-1269.

581 Lee, K. \& Dunton, K.H. (2000). Effects of nitrogen enrichment on biomass allocation, growth, 582 and leaf morphology of the seagrass Thalassia testudinum. Mar. Ecol. Prog. Ser., 196, 3958348. 
584 Lin, G., Banks, T. \& da Silveria Lobo O’Reilly Sternberg, L. (1991). Values for the seagrass

585 Thalassia testudinum and its relations to mangrove carbon. Aquat. Biol., 40, 333-341.

586 Lloyd, R.M. (1964). Variations in the oxygen and carbon isotope ratios of Florida Bay mollusks

587 and their environmental significance. J. Geol., 72, 84-111.

588 López-Calderón, J.M., Guzmán, H.M., Jácome, G.E. \& Barnes, P.A.G. (2013). Decadal increase

589 in seagrass biomass and temperature at the CARICOMP site in Bocas del Toro, Panama.

590 Rev. Biol. Trop., 61, 1815-1826.

591 Mcclelland, J.W., Valiela, I. \& Michener, R.H. (1997). Nitrogen-stable isotope signatures in

592 estuarine food webs : A record of increasing urbanization in coastal watersheds. Limnol.

593 Oceanogr., 42, 930-937.

594 Oksanen, J., , Blanchet, J.F., Friendly, M., Kindt, R., Legendre, P., McGlinn, D., Minchin, P. R., 595 O'Hara, R.B., Simpson, G.L., Solymos, P., Stevens, M.H.H., Szoecs, E., Wagner, H. (2020). 596 vegan: Community Ecology Package.

597 O’Leary, J.K., Micheli, F., Airoldi, L., Boch, C., Leo, G.D.E., Elahi, R., Ferretti, F., Graham, 598 N.A.J., Litvin, S.Y., Low, N.H., Lummis, S., Nickols, K.J., Wong, J. (2017). The resilience 599 of marine ecosystems to climatic disturbances. Bioscience, 67, 208-220.

600 Orth, R.J., Carruthers, T.J.B., Dennison, W.C., Duarte, C.M., Fourqurean, J.W., Heck, K.L., 601 Hugues, R. A., Kendrick, G.A., Kenworthy, W.J., Olyarnik, S., Short, F.T., Waycott, M., 602 Williams, S.L. (2006). A global crisis for seagrass ecosystems. Bioscience, 56, 987-996.

603 Phillips, S., Rouse, G.E. \& Bustin, R.M. (1997). Vegetation zones and diagnostic pollen profiles 604 of a coastal peat swamp, Bocas del Toro, Panama. Palaeogeogr. Palaeoclimatol. 605 Palaeoecol., 128, 301-338.

606 Seemann, J., González, C.T., Carballo-bolaños, R., Berry, K., Heiss, G.A., Struck, U., 
607

608

609

610

611

612

613

614

615

616

617

618

619

620

621

622

623

624

625

626

627

628

629

Leinfelder, R.R. (2014). Assessing the ecological effects of human impacts on coral reefs in Bocas del Toro, Panama. Environ. Monit. Assess., 186, 1747-1763.

Seemann, J., Yingst, A., Stuart-smith, R.D., Edgar, G.J. \& Altieri, A.H. (2018). The importance of sponges and mangroves in supporting fish communities on degraded coral reefs in Caribbean Panama. PeerJ, 6:e4455, 1-22.

Short, F., Carruthers, T., Dennison, W. \& Waycott, M. (2007). Global seagrass distribution and diversity: A bioregional model. J. Exp. Mar. Bio. Ecol., 350, 3-20.

Short, F.T., Koch, E.W., Creed, J.C., Magalha, K.M., Fernandez, E. \& Gaeckle, J.L. (2006). SeagrassNet monitoring across the Americas : case studies of seagrass decline. Mar. Ecol., $27,277-289$.

Sievers, M., Brown, C.J., Tulloch, V.J.D., Pearson, R.M., Haig, J.A., Turschwell, M.P., Connolly, R. M. (2019). The role of vegetated coastal wetlands for marine megafauna conservation. Trends Ecol. Evol., 34, 807-817.

Udy, J.W. \& Dennison, W.C. (1997). Growth and physiological responses of three seagrass species to elevated sediment nutrients in Moreton Bay, Australia. J. Exp. Mar. Bio. Ecol., $217,253-277$.

United Nations Environment Programme (2020). Out of the blue: The value of seagrasses to the environment and to people. UNEP, Nairobi.

van Tussenbroek, B.I., Corés, J., Collin, R., Fonseca, A.C., Gayle, P.M.H., Guzman, H.M., Jacome, G.E., Juman, R., Koltes, K.H., Oxenford, H.A., Rodrıguez-Ramirez, A., SamperVillarreal, J., Smith, S.R., Tschirky, J.J., Weil, E. (2014). Caribbean-wide, long-term study of seagrass beds reveals local variations, shifts in community structure and occasional collapse. PLoS One, 9, e90600. 
630 Waycott, M., Duarte, C.M., Carruthers, T.J.B., Orth, R.J., Dennison, W.C., Olyarnik, S.,

631 Calladine, A., Fourqurean, J.W., Heck, K.L., Hughes, A.R., Kendrick, G.A., Kenworthy,

632 W.J., Short, F.T., Williams, S.L. (2009). Accelerating loss of seagrasses across the globe 633 threatens coastal ecosystems. PNAS, 1, 1-5.

634 Wickham H (2016). ggplot2: Elegant graphics for data analysis. Springer-Verlag New York. 635 ISBN 978-3-319-24277-4.

636 Wickham H, Averick M, Bryan J, Chang W, McGowan LD, François R, Grolemund G, Hayes 637 A, Henry L, Hester J, Kuhn M, Pedersen TL, Miller E, Bache SM, Müller K, Ooms J, 638 Robinson D, Seidel DP, Spinu V, Takahashi K, Vaughan D, Wilke C, Woo K, Yutani H 639 (2019). "Welcome to the tidyverse." Journal of Open Source Software, 4(43), 1686.

640 Williams, S.L. (1987). Competition between the seagrasses Thalassia testudinum and 641 Syringodium filiforme in a Caribbean lagoon. Mar. Ecol. Prog. Ser., 35, 91-98. 


\section{Table 1 (on next page)}

Seagrass physical characteristics

Percentage cover in transects, average shoot morphometrics (shoot area, leaf length and leaf width) and biomass (aboveground) of Thalassia testudinum across sites in Bahía Almirante ( $\mathrm{SE}=$ standard error, $\mathrm{CV}=$ coefficient of variation). 
1 Table 1. Percentage cover in transects, average shoot morphometrics (shoot area, leaf length and 2 leaf width) and biomass (aboveground) of Thalassia testudinum across sites in Bahía Almirante $3(\mathrm{SE}=$ standard error, $\mathrm{CV}=$ coefficient of variation).

4

\begin{tabular}{|cccccc|}
\hline & $\begin{array}{c}\text { \% cover of } \\
\boldsymbol{T} \text {. } \\
\text { testudinum }\end{array}$ & $\begin{array}{c}\text { Average } \\
\text { shoot area } \\
\left(\mathrm{mm}^{2}\right)\end{array}$ & $\begin{array}{c}\text { Average } \\
\text { leaf length } \\
(\mathrm{mm})\end{array}$ & $\begin{array}{c}\text { Average } \\
\text { leaf width } \\
(\mathrm{mm})\end{array}$ & $\begin{array}{c}\text { Biomass } \\
(\mathrm{g} \text { dry mass } \\
\left.\mathrm{m}^{2}\right)\end{array}$ \\
\hline Mean & 51.95 & 6395 & 190 & 11 & 71.7 \\
SE & 5.85 & 970 & 18 & 0.4 & 8.1 \\
$\mathrm{CV}$ & 0.53 & 0.61 & 0.39 & 0.15 & 0.56 \\
Median & 52.68 & 6218 & 187 & 11 & 71.7 \\
Minimum & 5.20 & 656 & 41 & 8 & 24.8 \\
Maximum & 91.57 & 15690 & 304 & 14 & 139.6 \\
$\mathrm{n}$ & 22 & 16 & 16 & 16 & 24 \\
\hline
\end{tabular}

5

6 


\section{Table 2 (on next page)}

Seagrass Elemental Characteristics

Elemental content and stable isotope ratios of Thalassia testudinum leaves collected across the 24 sites in Bahía Almirante. (\%N, \%C and \%P are \% of dry weight). LI= limitation index, $n=24$. 
1

2 Table 2. Elemental content and stable isotope ratios of Thalassia testudinum leaves collected

3 across the 24 sites in Bahía Almirante. $(\% \mathrm{~N}, \% \mathrm{C}$ and $\% \mathrm{P}$ are $\%$ of dry weight). $\mathrm{LI}=$ limitation 4 index, $n=24$.

\begin{tabular}{|c|c|c|c|c|c|c|c|c|c|}
\hline & $\% \mathrm{~N}$ & $\% \mathrm{C}$ & $\% \mathbf{P}$ & $C: N$ & $\mathrm{C}: \mathrm{P}$ & $\mathbf{N}: \mathbf{P}$ & LI & $\delta^{13} \mathrm{C}$ & $\delta^{15} \mathbf{N}$ \\
\hline Mean & 2.20 & 38.77 & 0.19 & 20.7 & 537.0 & 26.0 & 4.30 & -8.60 & 0.91 \\
\hline $\mathrm{SE}$ & 0.04 & 0.46 & 0.00 & 0.39 & 13.3 & 0.57 & 0.46 & 0.26 & 0.28 \\
\hline $\mathrm{CV}$ & 0.09 & 0.06 & 0.11 & 0.09 & 0.12 & 0.11 & 0.52 & 0.15 & 1.49 \\
\hline Median & 2.22 & 39.19 & 0.19 & 20.2 & 527.2 & 25.9 & 4.12 & -8.73 & 1.32 \\
\hline Minimum & 1.76 & 34.24 & 0.15 & 17.5 & 441.9 & 20.9 & 0.69 & -11.74 & -1.75 \\
\hline Maximum & 2.57 & 42.18 & 0.23 & 23.7 & 660.6 & 33.0 & 9.08 & -6.70 & 3.15 \\
\hline
\end{tabular}




\section{Table 3 (on next page)}

Correlations among seagrass characteristics

Correlations (non-parametric Spearman's $\rho$ ) among elemental and stable isotope ratios, LI and biomass of Thalassia testudinum and water depth. Correlation coefficients are indicated above the diagonal and the $p$-values (pairwise comparisons) are below. Significant $(p<0.05)$ correlations are indicated in bold. LI: Limitation Index. 
1 Table 3. Correlations (non-parametric Spearman's $\rho$ ) among elemental and stable isotope ratios, 2 LI and biomass of Thalassia testudinum and water depth. Correlation coefficients are indicated

3 above the diagonal and the $\mathrm{p}$-values (pairwise comparisons) are below. Significant $(\mathrm{p}<0.05)$

4 correlations are indicated in bold. LI: Limitation Index.

\begin{tabular}{|c|c|c|c|c|c|c|c|c|}
\hline & Depth & C:N & C:P & N:P & LI & Biomass & $\delta^{13} \mathrm{C}$ & $\delta^{15} \mathrm{~N}$ \\
\hline Depth & & 0.049 & $\mathbf{0 . 4 6 1}$ & 0.392 & -0.403 & -0.167 & 0.062 & -0.266 \\
\hline C:N & 0.820 & & $\mathbf{0 . 4 2 8}$ & -0.310 & 0.259 & 0.266 & 0.360 & 0.542 \\
\hline C:P & $\mathbf{0 . 0 2 3}$ & $\mathbf{0 . 0 3 7}$ & & $\mathbf{0 . 6 7 0}$ & $\mathbf{- 0 . 6 4 6}$ & -0.041 & 0.352 & -0.109 \\
\hline N:P & 0.058 & 0.141 & $<\mathbf{0 . 0 0 1}$ & & $\mathbf{- 0 . 9 7 6}$ & -0.118 & 0.131 & $\mathbf{- 0 . 5 0 2}$ \\
\hline LI & 0.051 & 0.221 & $\mathbf{0 . 0 0 1}$ & $<\mathbf{0 . 0 0 1}$ & & 0.103 & -0.095 & $\mathbf{0 . 4 6 3}$ \\
\hline Biomass & 0.436 & 0.209 & 0.850 & 0.582 & 0.633 & & 0.286 & 0.190 \\
\hline$\delta^{13} \mathrm{C}$ & 0.773 & 0.084 & 0.091 & 0.541 & 0.660 & 0.175 & & 0.119 \\
\hline$\delta^{15} \mathrm{~N}$ & 0.210 & $\mathbf{0 . 0 0 6}$ & 0.613 & $\mathbf{0 . 0 1 2}$ & $\mathbf{0 . 0 2 3}$ & 0.375 & 0.579 & \\
\hline
\end{tabular}

5 
Figure 1

Map of study area

Map of Bahía Almirante in the Bocas del Toro archipelago, Panama showing the 24 sampling sites used in this study (see table 1 for details).

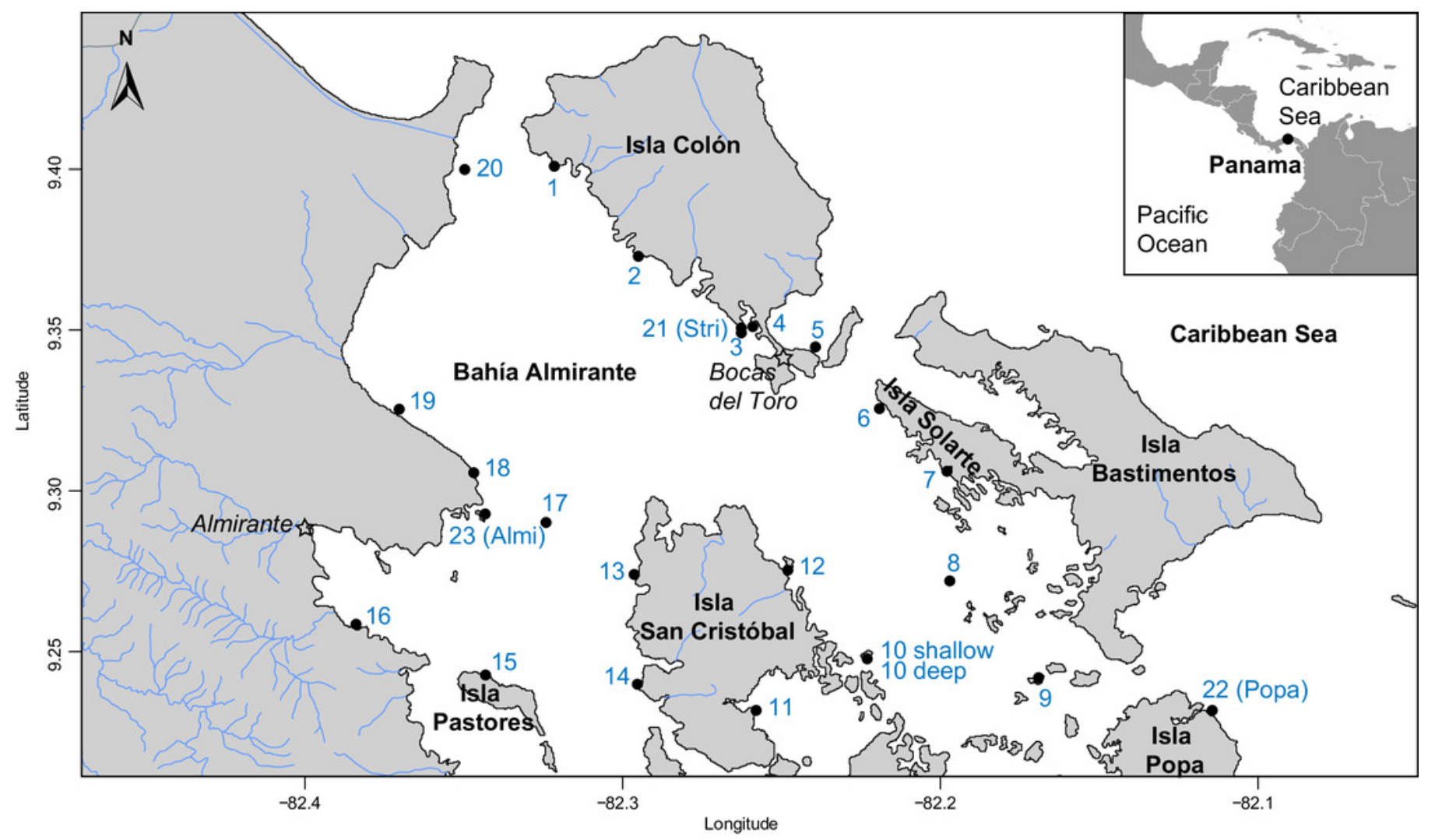


Figure 2

Frequency distributions of seagrass characteristics

Frequency distribution of the \% cover, biomass, leaf width of Thalassia testudinum, across sites in Bahía Almirante ( $n=22$ for \% Thalassia, $n=24$ for the biomass and $n=16$ for the leaf width).
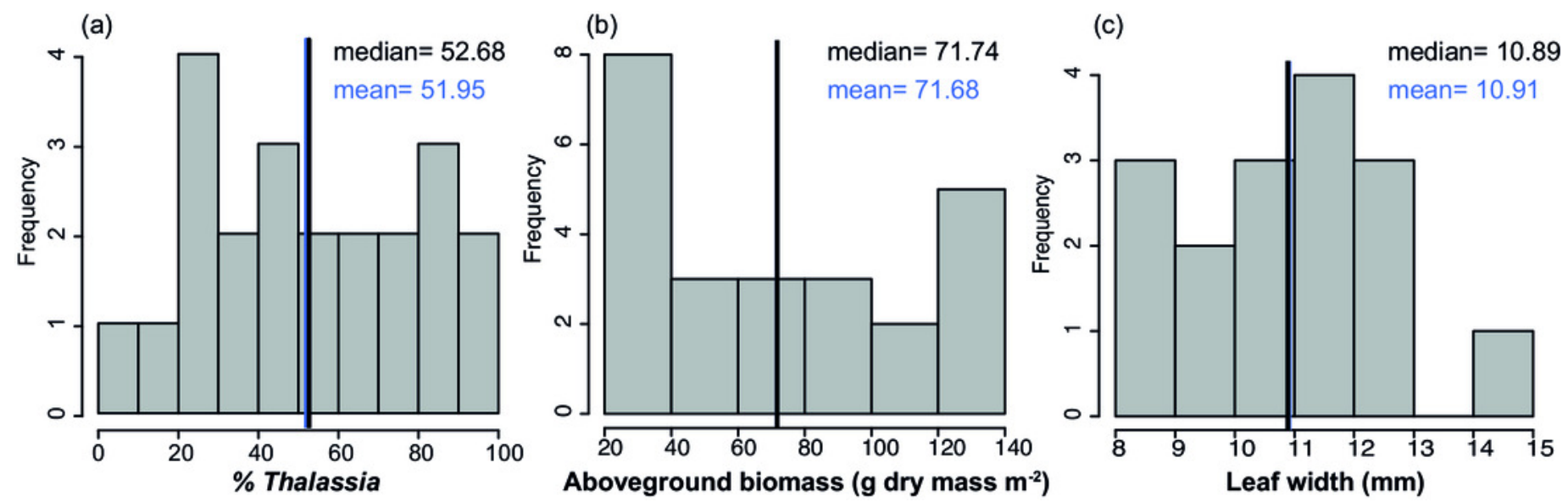
Figure 3

Benthic community composition across the sites throughout Bahía Almirante.

Benthic community composition across the sites throughout Bahía Almirante.

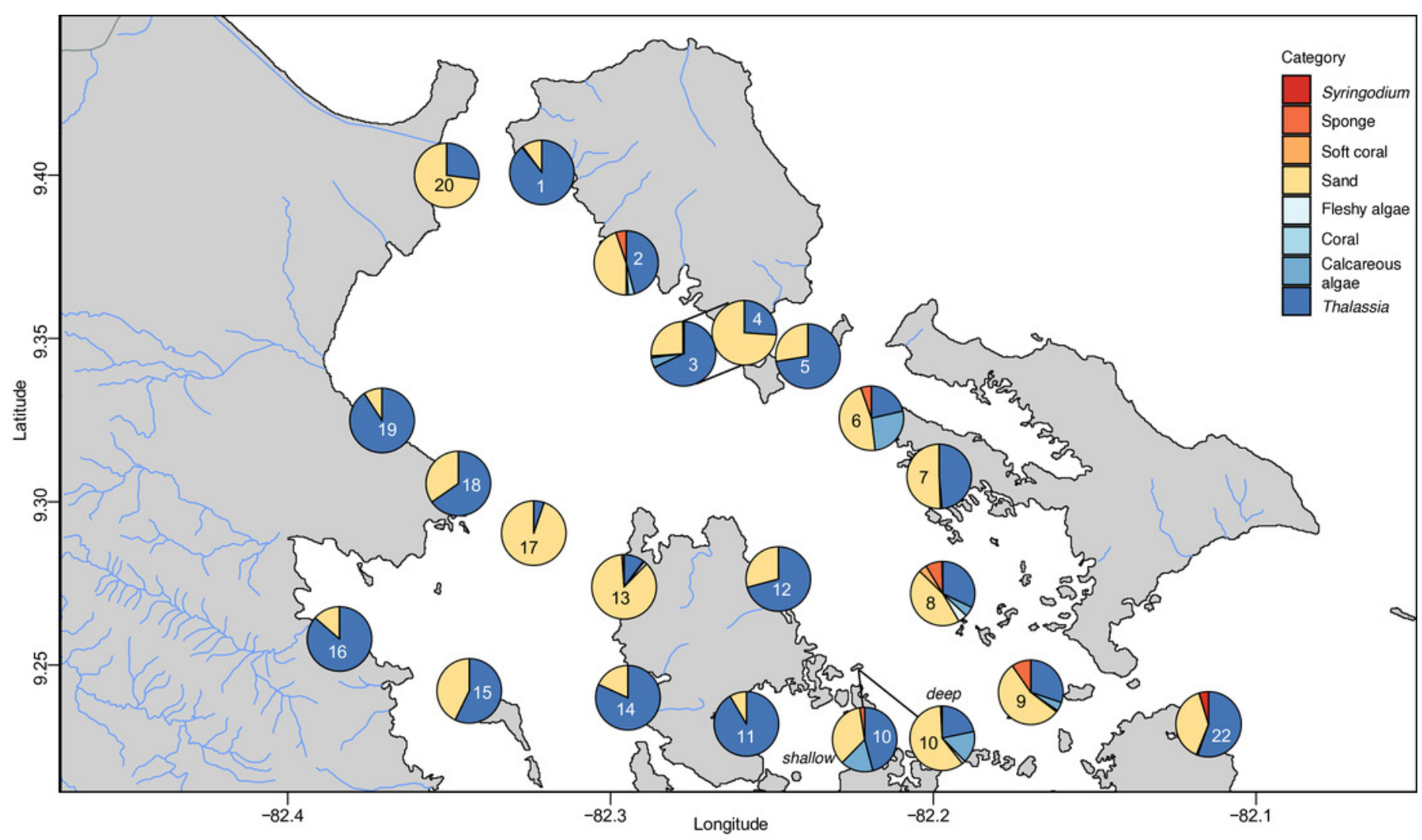


Figure 4

Relationship between depth and seagrass characteristics

Relationship between (a) the \% cover of Thalassia testudinum (y scale is log10 transformed) and depth, and (b) its biomass and depth. Linear regression and 95\% confidence interval (gray area) of the regression are indicated.
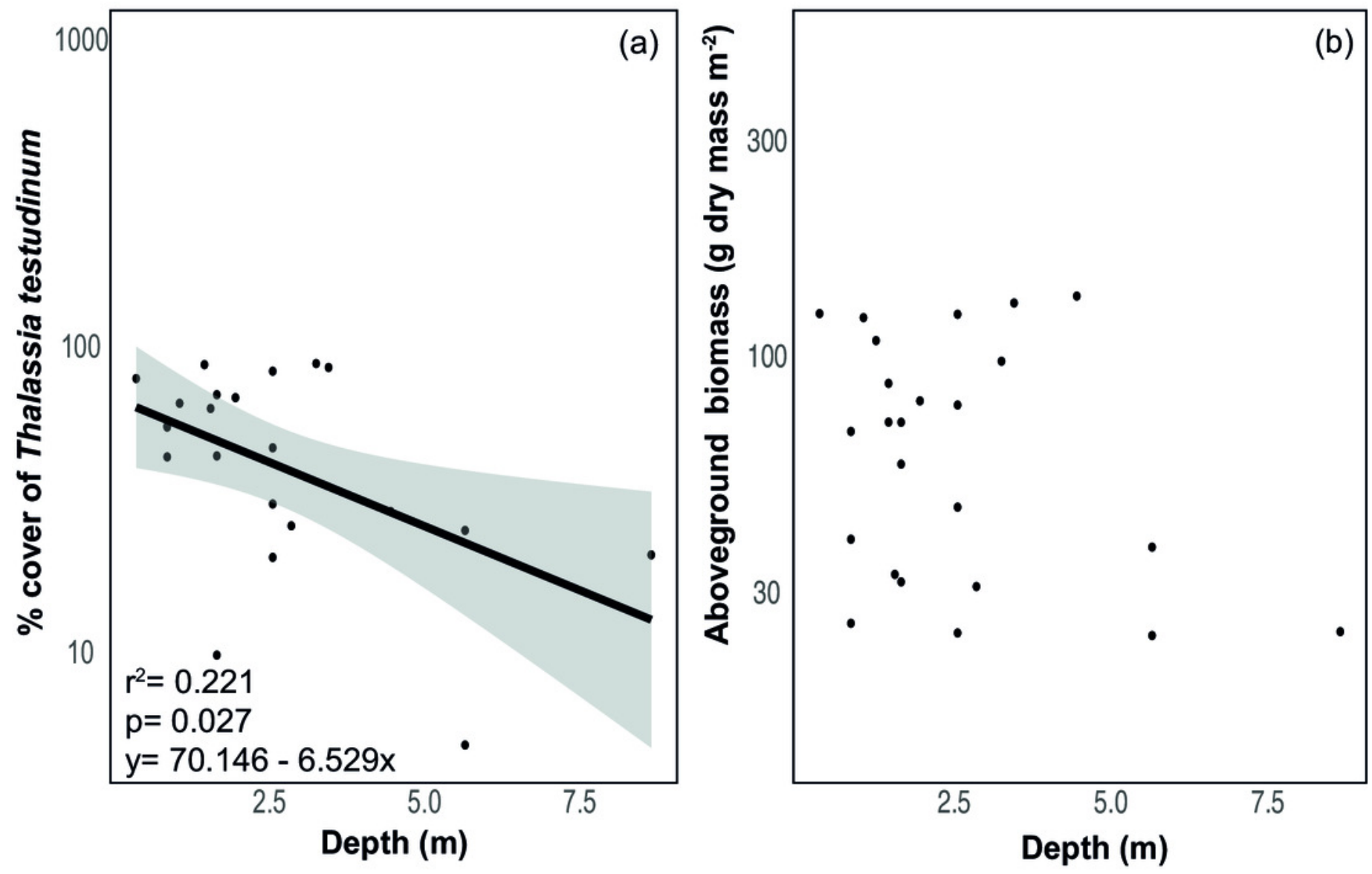
Figure 5

Bray-Curtis dissimilarity cluster analysis of benthic community composition across sites in Bahía Almirante

Bray-Curtis dissimilarity cluster analysis of benthic community composition across sites in Bahía Almirante (see Figure 1). 


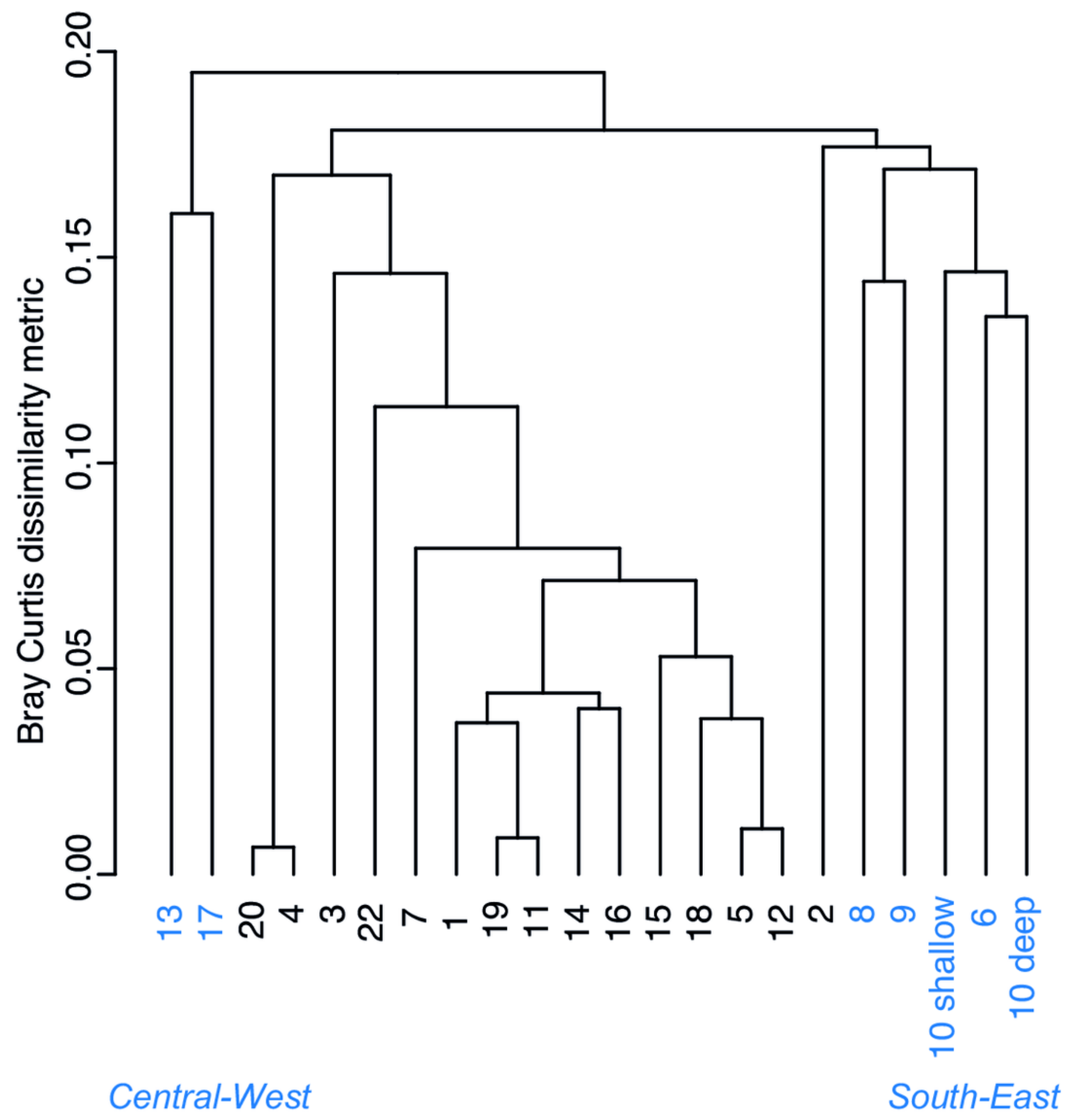


Figure 6

Frequency distributions of elemental characteristics

Frequency distributions of elemental ( $\mathrm{C}: \mathrm{N}, \mathrm{C}: \mathrm{P}$ and $\mathrm{N}: \mathrm{P})$ and stable isotopes $\left(\delta^{13} \mathrm{C}\right.$ and $\left.\delta^{15} \mathrm{~N}\right)$ ratios of Thalassia testudinum across the sites in Bahía Almirante $(n=24)$. Red lines indicate the mean values of these parameters previously found in Bahia Almirante (a; Carruthers et al. 2005).

(a)

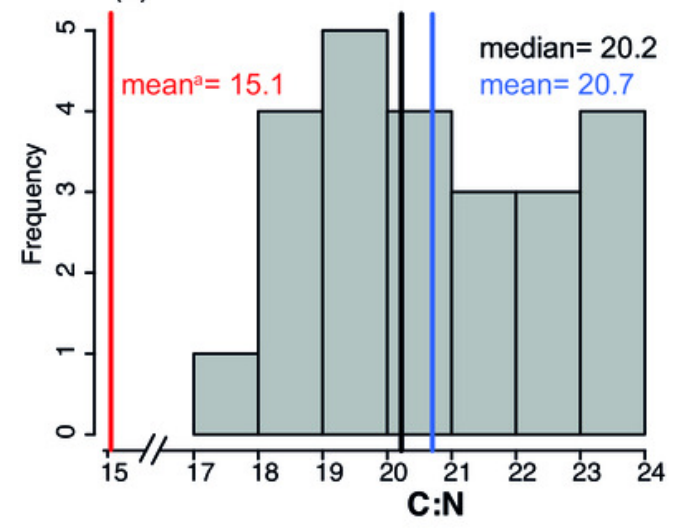

(b)

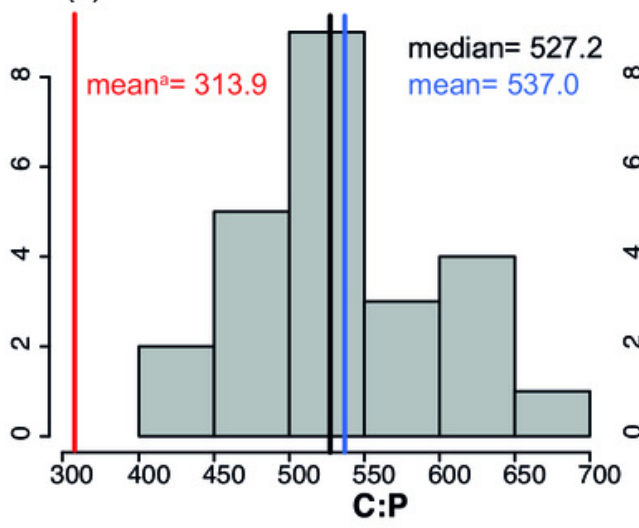

(c)

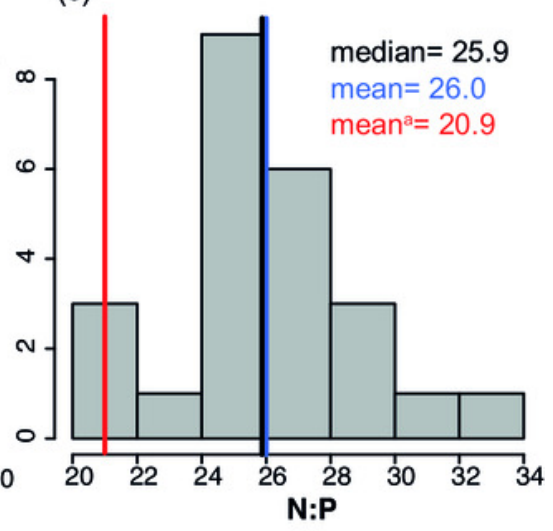

(d)
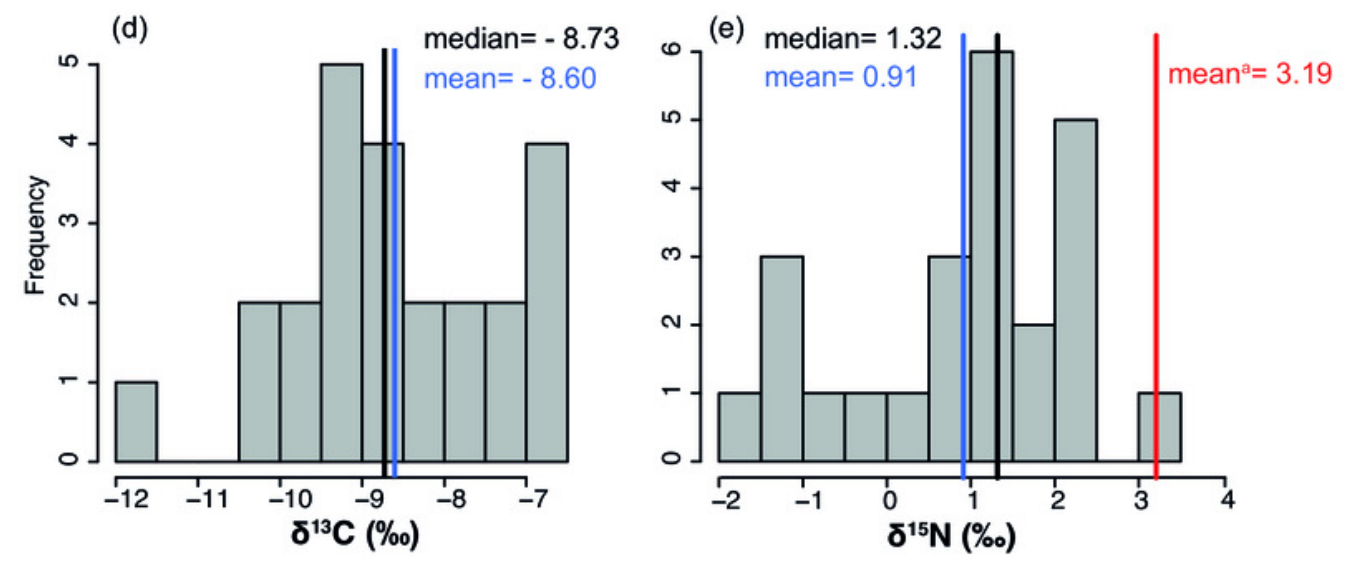
Figure 7

Relationships between seagrass structural and elemental characteristics

Relationship between (a) Thalassia testudinum biomass and its \%N (dry weight) or (b) its \%P (dry weight), (c) depth and its $\delta^{13} \mathrm{C}$ or (d) its $\delta^{15} \mathrm{~N}$ and (e) the distance to the open ocean and its ${ }^{13} \mathrm{C}$. Linear regression and $95 \%$ confidence interval (gray area) of the regression are indicated.
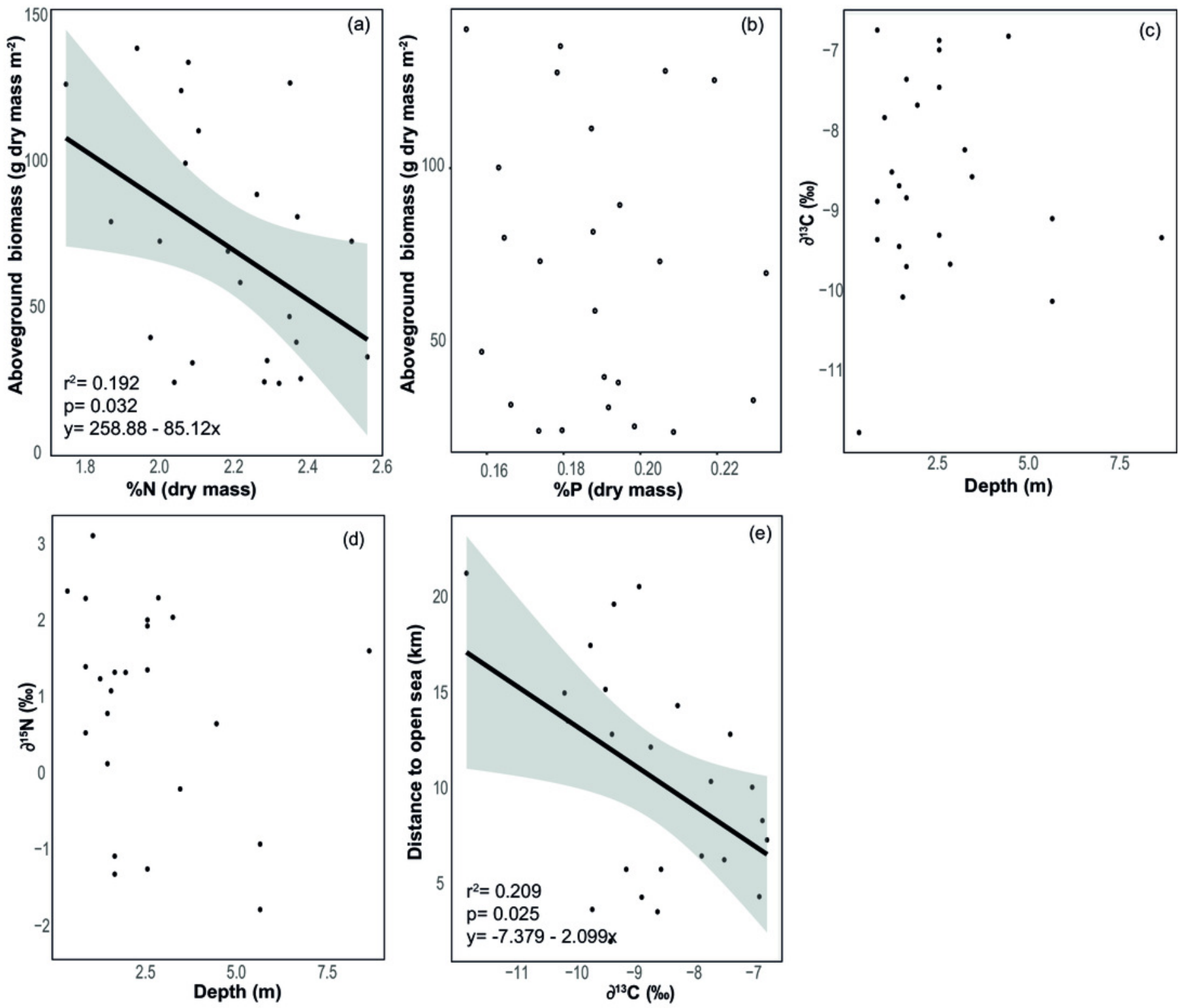


\section{Figure 8}

Literature search of T. testudinum nutrient content

Thalassia testudinum leaf nitrogen (\% $\mathrm{N}$ ) and phosphorus (\% P) content from different regions in the Caribbean, taken from the published literature. Regions are ordered by the mean for each nutrient, from the highest to the lowest. Each point represents a studied area for which the mean value ( \pm SE when available) was derived from the indicated reference in parenthesis (see Table S5 for the complete list of references). Numbers in square brackets correspond to the overall mean per region and to the total number of sites studied for this region. 
[mean, $n=$ total number of sites studied by region]

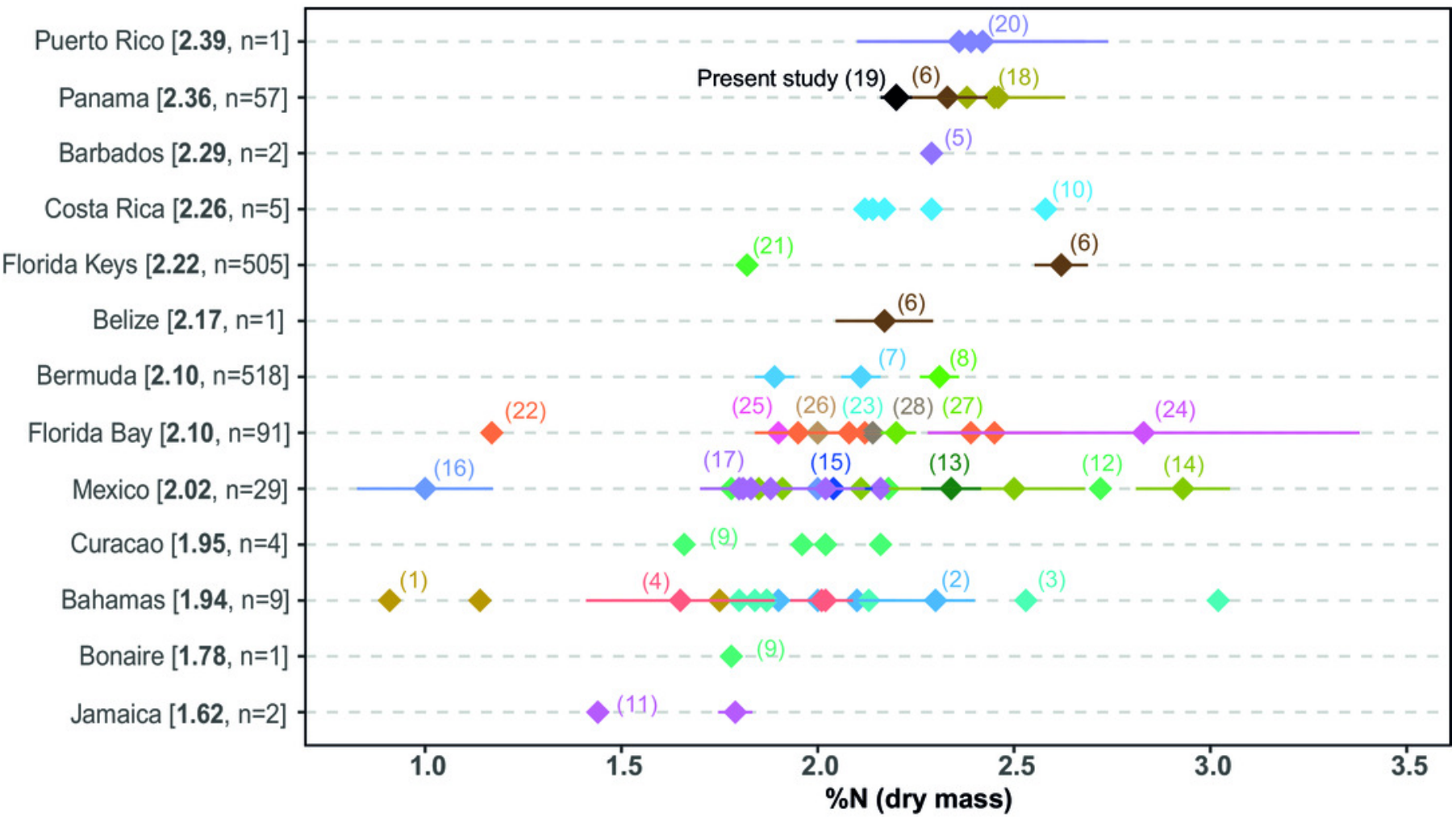

Costa Rica $[0.526, n=5]$

Panama $[0.22, n=57]$

Present study (19)

(10)

Curacao $[0.2, n=4]$

Bonaire $[0.17, \mathrm{n}=1]$

Barbados [0.157, n=2]

Mexico $[0.155, n=29]$

Puerto Rico $[0.154, n=1]$

Bahamas [0.154, n=9]

Bermuda [0.152, $\mathrm{n}=518]$.

Florida Keys [0.104, n=505]

Florida Bay [0.081, n=91]

Belize [0.075, n=1]

(6)

$(18)$

$(9)$

(5)

(16) (13)(15) (12)

(14)

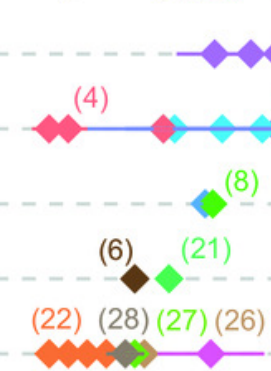

(20)

$(2)$
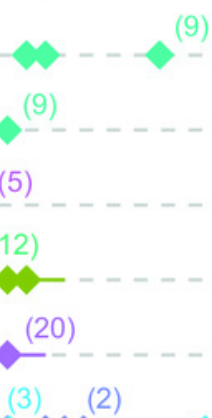

(7)

(24)

(6)

0.2

0.4

0.6

\%P (dry mass) 